\title{
Health law and policy: The scope and bounds of liberty?
}

A number of contributions to this month's issue tackle questions pertinent to the place of and limits to individual liberty in different health domains. These include the new medically assisted dying law in Canada, ${ }^{1}$ organ donation euthanasia in Belgium and the Netherlands, ${ }^{2}$ adolescent autonomy and refusals of treatment, ${ }^{3}$ and public health policy. ${ }^{4}$ Although spanning diverse areas of enquiry, each of these papers confronts aspects of the ongoing debate about how health-related law and policy ought to take account of competing moral claims and obligations within liberal society. Two of these articles, in particular, highlight the difficulties in balancing the needs and claims of individuals with those of society at large. Central to each are questions regarding the appropriate scope and bounds of individual autonomy and liberty.

The first of these by Schuklenk gives an insight into how this balance is translated into law and policy in one of the most controversial topics of recent times: assisted dying. ${ }^{1}$ The debate around Canada's new assisted dying legislation has brought to the fore the matter of conscientious objection, as well as the basis for such objection. ${ }^{i}$ Last year the prohibition against assisted dying was challenged and the Canadian Supreme Court unanimously held that the relevant sections of the Criminal Code "are of no force or effect to the extent that they prohibit physician-assisted death for a competent adult person who (1) clearly consents to the termination of life and (2) has a grievous and irremediable medical condition (including an illness, disease or disability) that causes enduring suffering that is intolerable to the individual in the circumstances of his or her condition" (at [147]). ${ }^{5}$

Schuklenk's article was written following the Supreme Court decision, but

${ }^{\mathrm{i}} \mathrm{A}$ forthcoming issue of the Journal will draw out some of these and includes an in-depth article by Schuklenk and Smalling on this.

Correspondence to: Prof Muireann Quigley, Newcastle University, Windsor Terrace, Newcastle upon Tyne, UK; muireann.quigley@newcastle.ac.uk before the relevant legislation was introduced. It outlines the major issues that Canada faced in the run up to enacting new legislation. Bill C-14 received Royal Assent in June 2016 and amends the Canadian Criminal Code with respect to medically assisted dying. One of the major issues noted by Schuklenk is that of conscientious objection. The Canadian Medical Association had argued that doctors should be obliged neither to assist with dying, nor to refer patients on to a colleague who would do so. Schuklenk takes a dim view of their stance. One of his major concerns is about the real-world effects that permitting conscientious objections might have on equitable access to healthcare services and the burden that individual patients may have to bear.

Schuklenk notes the difficulties with access to abortion services on Prince Edward Island. Because healthcare providers there do not offer such services, women have to travel to access a service to which they are legally entitled. Quite clearly, this is going to have disproportionate and negative consequences for those who cannot travel for financial and other reasons (see page 490). He is concerned that inequitable access to medically assisted dying might also be the consequence if health care professionals are permitted to conscientiously object. A longer article by Schuklenk and Smalling in our forthcoming conscientious objection issue will give a more in-depth analysis of the ethical issues around conscientious objection, as part of a special issue on the topic, which will also lay out the arguments in favour of such objections. One question they will tackle there is whether it is reasonable in a pluralistic society to view physicians (who voluntarily join the profession) as having the liberty to conscientiously object to services which are legally permitted.

The role of the state in either ensuring or constraining individual liberty also forms part of Dawson's article 'Snakes and ladders: state intervention and the place of liberty in public health'. Here Dawson questions the seeming privileging of liberty as a value in the Nuffield Council on Bioethics' intervention ladder. The ladder is presented in their report Public Health: Ethical Issues as a tool for thinking about public health interventions (p. 42). ${ }^{6}$ There is, Dawson says, a fundamental incoherence between the Council's recognition of liberal society's value pluralism and the intervention ladder. This is because the ladder essentially focuses on liberty as the singular value at issue. Moreover, the ladder itself embodies a 'least restrictive alternative' (LRA) approach; that is, it moves from least restrictive to most restrictive and presents them as a set of progressive, but linear steps (see page 510). ${ }^{4}$ LRA approaches, however, are problematic: " $[\mathrm{t}] \mathrm{he}$ very idea of the LRA encourages the idea that each value is separate and we want the most or least of something ... the focus on liberty assumes that we can make judgements about this one value in isolation from all others" (see page 510). ${ }^{4}$

Both of these articles raise important questions regarding the relationship between the state, state actors, and the citizenry in the health arena. As important as they are, liberty and supposedly libertybased moral claims ought not necessarily to be taken either (a) at face value or (b) as the moral trump card when determining justified health law and policy at state level. Assessing laws and policies which impact on whole populations requires us to broaden our moral horizons; not in the least because if we are not careful, we end up with liberty for the few at the expense of the welfare and equality (and thus liberty) of the many.

\section{REFERECNES}

1 Schuklenk U. Canada on course to introduce permissive assisted dying regime. J Med Ethics 2016;42:490-2

2 Bollen J, ten Hoopen R, Ysebaert D, et al. Legal and ethical aspects of organ donation after euthanasia in Belgium and the Netherlands. J Med Ethics 2016;42:486-9.

3 Brierley J, Larcher V. Adolescent autonomy revisited: clinicians need clearer guidance. J Med Ethics 2016;42:482-5

4 Dawson AJ. Snakes and ladders: state intervention and the place of liberty in public health. J Med Ethics 2016;42:510-3

5 Carter v. Canada (Attorney General), 2015 SCC 5 , [2015] 1 S.C.R. 331

6 Nuffield Council on Bioethics, Public Health: Ethical Issues London: Nuffield Council On Bioethics, 2007. 